\title{
Faktor-faktor yang Berhubungan dengan Perilaku Kunjungan Lansia ke Posyandu Lansia di Kerja Puskesmas Kampar Kabupaten Kampar Tahun 2013
}

\section{Faktors Related To The Elderly Visit Behavior Of To Seniorsin The Work Area Ihc Health Center Kampar Regency In 2013}

\section{Alhidayati}

Program Studi Ilmu Kesehatan Masyarakat, STIKes Hang Tuah Pekanbaru

\begin{abstract}
ABSTRAK
Jumlah kunjungan lansia ke Posyandu lansia dari tahun ke tahun masih rendah, karena masih di bawah target Standar Pelayanan Minimal (SPM) yaitu sebesar 70\%. Penelitian ini bertujuan untuk diketahuinya faktor-faktor yang berhubungan terhadap perilaku kunjungan lansia ke posyandu lansia yaitu Pengetahuan, Sikap, Dukungan Keluarga, Peran Petugas Kesehatan, Akses, Status Pekerjaan, Pendidikan, Jenis Kelamin, Umur. Jenis Penelitian yang digunakan adalah Studi Penampang Analitik (Analitik Cross Sectional Study) dengan jumlah sampel 250 orang. Proses pengambilan sampel dilakukan dengan cara Proportional Random Sampling, Analisis data dilakukan secara univariat, bivariat, dan multivariat dengan Uji Regresi Logistik Ganda. Hasil penelitian ini adalah proporsi lansia yang berkunjung ke posyandu 102 orang (40,8\%), dan yang tidak berkunjung 148 orang (59,2\%). Sedangkan variabel pengetahuan didapat POR 8,2 (95\% CI: 4,3-15,7), sikap POR 2,1 (95\% CI: 1,16-3,9), dukungan keluarga POR 2,4 (1,27-4,64), peran petugas kesehatan POR 2,6 (95\% CI: 1,36-5,32), akses POR 2,09 ( 95\% CI: 1,12-3,9), pendidikan POR 2,3 (95\% CI: 1,1-4,86). Kesimpulan dalam penelitian ini adalah bahwa ada hubungan antara Pengetahuan, Sikap, Dukungan Keluarga, Peran Petugas Kesehatan, Akses, Pendidikan dengan perilaku kunjungan lansia ke posyandu lansia. Saran bagi petugas perlu adanya promosi kesehatan secara terencana, terarah, dan berkesinambungandan kepada petugas segera memvariasikan kegiatan yang ada diposyandu, dan bagi keluarga harus selalu memberikan dukungan dan siap mengantar lansia keposyandu.
\end{abstract}

Kata Kunci : Perilaku Kunjungan, Posyandu lansia, Pengetahuan

\section{ABSTRACT}

For the number of visits to the elderly elderly IHC from year to year is low, as it is still below the target minimum service standards (MSS) which is 70\%. This study aims at knowing the factors related to the behavior of the elderly to visit the elderly posyandu Knowledge, Attitude, Family Support, The Role of Health Personnel, Access, Employment Status, Education, Gender, Age. Type of research is the study used cross-Analytical (Analytical Cross Sectional Study) with a sample of 250 people. The sampling process is done by proportional random sampling, data analysis was performed using univariate, bivariate, and multivariate logistic regression Test Doubles. Results of this study was the proportion of elderly who visited posyandu 102 people (40.8\%), and 148 people who did not visit (59.2\%). While the variable knowledge gained POR 8.2 (95\% CI: 4.3 to 15.7), attitude POR 2.1 (95\% CI: 1.16 to 3.9), family support POR 2.4 (1, 27 to 4.64), the role of health workers POR 2.6 (95\% CI: 1.36 to 5.32), access POR 2.09 (95\% CI: 1.12 to 3.9), education POR 2 , 3 (95\% CI: 1.1 to 4.86). The conclusion of this study is that there is a relationship between the Knowledge, Attitude, Family Support, The Role of Health Personnel, Access, Education to conduct neighborhood health center visits to elderly seniors. Advice for health promotion officer needs to be planned, directed, and sustained and the officer immediately diposyandu varying the existing activities, and the family must always provide support and are available to take seniors keposyandu.

Keywords: Behavior Visits, IHC elderly, Knowledge

\section{PENDAHULUAN}

Lanjut usia adalah penduduk yang telah mencapai usia 60 tahun ke atas (UU No 13 Tahun 1998 tentang kesejahteraan lanjut usia). Sedangkan menurut Maryam (2008) usia lanjut dikatakan sebagai tahap akhir perkembangan pada dasar kehidupan manusia. Usia lanjut termasuk kelompok yang rentan terhadap berbagai masalah psikososial dan rawan kesehatan, khususnya terhadap kemungkinan jatuh sakit dan ancaman kematian, karena mereka menghadapi berbagai masalah yang berkaitan dengan proses menua yang dialaminya (Depkes RI, 2003).

Alamat Korespodensi : Alhidayati, Prodi IKM STIKes Hang Tuah Pekanbaru, Hp: 08526552200, email: alhidayati.skm@gmail.com 
Jenis penyakit yang diderita usia lanjut pada umumnya merupakan penyakit degeneratif yang bersifat kronis dan kompleks yang membutuhkan biaya yang relatif tinggi untuk perawatannya, seperti penyakit sendi, hipertensi, diabetes mellitus. Oleh karena itu sangat efisien apabila kondisi sehat dan mandiri dapat dipertahankan selama mungkin. Hal tersebut diupayakan dengan peningkatan upaya promotif dan preventif melalui kegiatan pada kelompok usia lanjut (Depkes RI, 2003).

Sebagai wujud nyata pelayanan sosial dan kesehatan pada kelompok usia lanjut ini, pemerintah telah mencanangkan pelayanan pada lansia melalui beberapa jenjang. Pelayanan kesehatan di tingkat masyarakat adalah posyandu lansia, pelayanan kesehatan lansia tingkat dasar adalah Puskesmas , dan pelayanan kesehatan tingkat lanjutan adalah Rumah Sakit. Salah satu pelayanan kesehatan yang berada dekat dengan masyarakat dan dapat di manfaatkan oleh seluruh masyarakat khususnya pada lansia yaitu posyandu lansia (Erfandi, 2008).

Puskesmas Kampar merupakan salah satu Puskesmas yang ada di wilayah kerja Dinas Kesehatan Kabupaten Kampar. Berdasarkan data dari Puskesmas Kampar, wilayah kerja Puskesmas Kampar mempunyai 18 desa, satu desa mempunyai satu posyandu lansia. Untuk jumlah kunjungan lansia ke Posyandu lansia dari tahun ke tahun masih rendah, karena masih di bawah target Standar Pelayanan Minimal (SPM) yaitu sebesar 70\%.

Berdasarkan uraian diatas dapat dilihat bahwa masih banyaknya lansia yang belum mengikuti posyandu lansia. Berdasarkan Undang-Undang No. 36 Tahun 2009 tentang kesehatan pasal 138 bahwa pemerintah wajib menjamin ketersediaan fasilitas pelayanan kesehatan dan memfasilitasi kelompok lansia untuk dapat hidup mandiri dan produktif. Berdasarkan hal diatas program posyandu lansia ini sangat bermanfaat sekali bagi lansia. Dari uraian inilah maka peneliti tertarik untuk melakukan penelitian terhadap faktor-faktor yang berhubungan terhadap perilaku kunjungan lansia ke posyandu lansia di wilayah kerja Puskesmas Kampar Kabupaten Kampar Tahun 2013.

\section{METODE}

Penelitian bersifat kuantitatif dengan jenis desain studi penampang analitik (analytic crosssectional Study) dengan mana variabel independen dan variabel dependen ditanyakan dalam waktu yang sama kepada responden (Lapau, 2012). Sampel dari penelitian ini adalah sebagian dari populasi yang terdiri dari lansia yang berada di wilayah kerja Puskesmas Kampar Kabupaten Kampar Tahun 2013.

Wilayah kerja Puskesmas Kampar memiliki 18 desa, yang masing-masing desa mempunyai 1 posyandu lansia. Dari jumlah lansia yang ada di wilayah kerja Puskesmas Kampar sebanyak 2.184 lansia. Akan diambil sampel 250 orang dengan prosedur "Proportional Random Sampling".

Analisa data dilakukan secara bertahap yang meliputi analisis univariat, bivariat dilakukan dengan Uji Chi Square dan multivariat dengan uji regresi logistik ganda.

\section{HASIL}

\section{Analisi Univariat}

Hasil analisis univariat menunjukkan bahwa $68,8 \%$ lansia pengetahuan rendah, 54,0\% lansia sikap negatif, 47,6\% lansia dengan keluarga yang tidak mendukung, 35,2\% lansia peran petugas kesehatan tidak berperan, 56,8\% lansia akses jauh, 19,2\% lansia bekerja, 78,4\% lansia pendidikan rendah, 35,2\% lansia laki-laki, 32,0\% lansia umur 45-59 tahun. Dan terdapatnya variabel yang homogeny (salah satu kategorinya mempunyai nilai $<20 \%$ ) yaitu variabel status pekerjaan karena kategori bekerja hanya 19,2\%.

\section{Analisis Bivariat}

Hasil uji bivariat menunjukkan bahwa ada 4 variabel independen yang berhubungan signifikan dengan perilaku kunjungan lansia ke posyandu lansia, Pengetahuan rendah berpengaruh 8,5 kali untuk tidak berkunjung ke posyandu lansia dibandingkan dengan lansia dengan pengetahuan tinggi (C.I. 95\%: POR= 4,802-15,33), Sikap negatif berpengaruh 2,4 kali untuk tidak berkunjung ke posyandu lansia dibandingkan dengan lansia dengan sikap positif (C.I. 95\%: POR $=1,441-4,048)$, Akses jauh berpengaruh 2,2 kali untuk tidak berkunjung ke posyandu lansia dibandingkan dengan lansia dengan akses dekat (C.I 95\%: POR $=1,342-3,764)$, Pendidikan rendah berpengaruh 2,8 kali untuk tidak berkunjung ke posyandu lansia dibandingkan dengan lansia dengan pendidikan tinggi (C.I 95\%: POR =1,555-5,38) (lihat tabel 1).

\section{Analisis Multivariat}

\section{Seleksi Bivariat}

Hasil seleksi bivariat pada table 1 menunjukkan bahwa semua variabel menghasilkan $\mathrm{P}<$ 0,25 oleh karena itu semua variabel akan diikutkan dalam analisis multivariat yaitu variabel pengetahuan, sikap, dukungan keluarga, peran petugas kesehatan, akses, status pekerjaan, pendidikan, jenis kelamin, dan umur.

\section{Permodelan Multivariat Akhir}

Pada tabel 2 terlihat bahwa variabel yang berhubungan bermakna dengan perilaku kunjungan lansia ke posyandu lansia tahun 2013 adalah variabel pengetahuan, peran petugas, dukungan keluarga, sikap, akses dan pendidikan. Tidak ditemui adanya variabel counfonding. 
Tabel 1

Hubungan Beberapa Variabel Independen Terhadap Perilaku Kunjungan Lansia Ke Posyandu Lansia Tahun 2013

\begin{tabular}{|c|c|c|c|c|c|c|c|c|}
\hline \multirow{3}{*}{$\begin{array}{c}\text { Variabel Independen dan } \\
\text { Kategori }\end{array}$} & \multicolumn{4}{|c|}{$\begin{array}{c}\text { Perilaku Kunjungan Lansia ke } \\
\text { posyandu }\end{array}$} & \multicolumn{2}{|c|}{ Jumlah } & \multirow{3}{*}{ P value } & \multirow{3}{*}{$\begin{array}{l}\text { POR(95 } \\
\% \text { CI })\end{array}$} \\
\hline & \multicolumn{2}{|c|}{$\begin{array}{c}\text { Tidak } \\
\text { Berkunjung }\end{array}$} & \multicolumn{2}{|c|}{ Berkunjung } & \multirow[t]{2}{*}{$\mathbf{n}$} & \multirow[t]{2}{*}{$(\%)$} & & \\
\hline & $\mathbf{n}$ & $(\%)$ & $\mathbf{n}$ & $(\%)$ & & & & \\
\hline Pengetahuan & & & & & & & & 8,580 \\
\hline Rendah & 119 & $(78,3)$ & 33 & $(21,7)$ & 152 & $(100)$ & 0,000 & $(4,802-$ \\
\hline Tinggi & 29 & $(29,6)$ & 69 & $(70,4)$ & 98 & $(100)$ & & $15,330)$ \\
\hline Sikap & & & & & & & & 2,416 \\
\hline Negatif & 93 & $(68,9)$ & 42 & $(31,1)$ & 135 & $(100)$ & 0,001 & $(1,441-$ \\
\hline Positif & 55 & $(47,8)$ & 60 & $(52,2)$ & 115 & $(100)$ & & $4,048)$ \\
\hline Dukungan Keluarga & & & & & & & & 1,549 \\
\hline Tidak Mendukung & 77 & $(64,7)$ & 42 & $(35,3)$ & 119 & $(100)$ & 0,119 & $(0,931-$ \\
\hline Mendukung & 71 & $(54,2)$ & 60 & $(45,8)$ & 131 & $(100)$ & & 2,578 \\
\hline Peran Petugas Kesehatan & & & & & & & & 1,547 \\
\hline Tidak Berperan & 58 & $(65,9)$ & 30 & $(34,1)$ & 88 & $(100)$ & 0,145 & $(0,902-$ \\
\hline Berperan & 90 & $(55,6)$ & 72 & $(44,4)$ & 162 & $(100)$ & & $2,651)$ \\
\hline Akses & & & & & & & & 2,247 \\
\hline Jauh & 96 & $(67,6)$ & 46 & $(34,1)$ & 142 & $(100)$ & 0,003 & $(1,342-$ \\
\hline Dekat & 52 & $(48,9)$ & 56 & $(44,4)$ & 108 & $(100)$ & & $3,764)$ \\
\hline Status Pekerjaan & & & & & & & & 1,664 \\
\hline Bekerja & 33 & $(68,8)$ & 15 & $(31,3)$ & 48 & $(100)$ & 0,182 & $(0,851-$ \\
\hline Tidak Bekerja & 115 & $(56,9)$ & 87 & $(43,1)$ & 202 & $(100)$ & & $3,255)$ \\
\hline Pendidikan & & & & & & & & 2,892 \\
\hline Rendah & 127 & $(64,8)$ & 69 & $(35,2)$ & 196 & $(100)$ & 0,001 & $(1,555-$ \\
\hline Tinggi & 21 & $(38,9)$ & 33 & $(61,1)$ & 54 & $(100)$ & & $5,380)$ \\
\hline Jenis Kelamin & & & & & & & & 1,435 \\
\hline Laki-laki & 57 & $(64,8)$ & 31 & $(35,2)$ & 88 & $(100)$ & 0,235 & $(0.839$ \\
\hline Perempuan & 91 & $(56,2)$ & 71 & $(43,8)$ & 162 & $(100)$ & & $2,453)$ \\
\hline Umur & & & & & & & & 1,550 \\
\hline 45-59 Tahun & 53 & $(66,3)$ & 27 & $(33,8)$ & 80 & $(100)$ & 0,156 & $(0,891-$ \\
\hline 60-69 Tahun & 95 & $(55,9)$ & 75 & $(44,1)$ & 170 & $(100)$ & & $2,696)$ \\
\hline
\end{tabular}

Tabel 2

Permodelan Multivariat Akhir Faktor-faktor yang Berhubungan terhadap Perilaku Kunjungan Lansia ke Posyandu Lansia di Wilayah Kerja Puskesmas Kampar Kabupaten Kampar Tahun 2013

\begin{tabular}{lccc}
\hline Variabel Independen & $\begin{array}{l}\text { P } \\
\text { value }\end{array}$ & POR & $(95 \%$ CI $)$ \\
\hline Pengetahuan & 0,000 & 8,298 & $4,378-15,729$ \\
Sikap & 0,015 & 2,152 & $1,160-3,991$ \\
Dukungan Keluarga & 0,007 & 2,435 & $1,278-4,640$ \\
Peran Petugas Kesehatan & 0,004 & 2,690 & $1,360-5,321$ \\
Akses & 0,020 & 2,093 & $1,122-3,905$ \\
Status Pekerjaan & - & - & - \\
Pendidikan & 0,027 & 2,314 & $1,101-4,865$ \\
\hline
\end{tabular}

\section{PEMBAHASAN}

Hubungan Pengetahuan dengan Perilaku Kunjungan Lansia ke Posyandu Lansia

Pengetahuan berhubungan sebab akibat dengan perilaku kunjungan ke posyandu lansia. Pengetahuan yang rendah akan mempengaruhi seseorang untuk tidak hadir ke posyandu karena mereka tidak mengetahui apa itu manfaat berkunjung posyandu lansia. Pengetahuan yang rendah tentang manfaat berkunjung posyandu lansia dapat diperoleh dari pengalaman pribadi dalam kehidupan sehariharinya dengan menghadiri kegiatan yang ada posyandu lansia, mereka akan mendapatkan penyuluhan tentang bagaimana cara hidup sehat dengan segala keterbatasan atau masalah yang melekat pada diri mereka. Dengan pengalaman inilah nantinya pengetahuan tersebut akan semakin meningkat dan menjadi dasar dalam pembentukan sikap sehingga 
dapat mendorong minat atau motivasi untuk selalu mengikuti kegiatan posyandu lansia.

Oleh karena itu perlu adanya peningkatan pengetahuan agar mereka lebih mengetahui manfaat apa saja yang diberikan apabila berkunjung ke posyandu lansia. Untuk itu diperlukan konseling dan promosi kesehatan melalui media yang menarik seperti ceramah, tanya jawab, leaflet. Dalam hal ini promosi dilakukan secara terencana, terarah, dan berkesinambungan sehingga dengan kegiatan promosi itulah nantinya mereka yang berpengetahuan rendah tersebut akan lebih mengetahui lagi apa itu posyandu lansia, kegiatan apa saja yang ada didalamnya, manfaat apa yang diberikan, keuntungan apa yang didapat sehingga mereka yang tidak berkunjung lebih termotivasi lagi untuk berkunjung ke posyandu lansia.

\section{Hubungan Peran Petugas Kesehatan dengan Perilaku Kunjungan Lansia ke Posyandu Lansia}

Peran petugas kesehatan berhubungan sebab akibat dengan perilaku kunjungan ke posyandu lansia. Tidak adanya peran petugas kesehatan terhadap keefektifan kader akan mempengaruhi seseorang untuk tidak berkunjung ke posyandu lansia. Petugas kesehatan ini bertugas dalam memberikan bimbingan Kepada kader agar adanya pembaharuan materi setiap satu bulan sekali sehingga nantinya kegiatan yang ada di posyandu dapat bervariasi . Bila kader tidak memberikan informasi kepada lansia maka lansia tidak akan berkunjung ke posyandu lansia. Kader selain mempunyai tugas dan fungsi juga harus bisa berkomunikasi dengan baik dan harus mampu mengajak dan memotivasi kelompok maupun masyarakat. Kader juga harus dapat membina semua yang terkait dengan pelaksanaan posyandu, dan memantau perkembangan lansia. Untuk meningkatkan citra diri kader maka harus dapat memperhatikan dan meningkatkan kualitas diri sebagai kader. Untuk itu disarankan agar memvariasikan pemeriksaan kesehatan yang ada diposyandu, tidak hanya pengukuran tekanan darah saja tetapi melakukan pemeriksaan air seni, pemeriksaan status mental (emosional), pemeriksaan adanya gula dalam air seni sebagai deteksi awal penyakit diabetes mellitus, pemeriksaan adanya zat putih telur (protein) dalam air seni sebagai deteksi awal adanya penyakit ginjal, kunjungan rumah oleh petugas bagi lansia yang tidak datang, pemberian makanan tambahan (PMT), mengaktifkan kembali senam lansia dan gerak jalan santai untuk meningkatkan kebugaran. Dengan adanya kegiatan yang bervariasi inilah maka seseorang akan lebih tertarik untuk berkunjung.

\section{Hubungan Dukungan Keluarga dengan Perilaku Kunjungan Lansia ke Posyandu Lansia}

Dukungan keluarga berhubungan sebab akibat dengan perilaku kunjungan ke posyandu lansia. Dukungan keluarga yang tidak mendukung akan mempengaruhi seseorang untuk tidak berkunjung ke posyandu lansia yang mana dukungan keluarga sangat berperan dalam mendorong minat atau ketersediaan untuk mengikuti kegiatan posyandu lansia. Dalam hal ini diperlukan dukungan keluarga karena keluarga merupakan salah satu motivator yang kuat. Oleh karena itu keluarga harus selalu siap mengantar, mengingatkan jadwal karena umumnya lansia hanya mengandalkan daya ingatnya saja walaupun petugas telah memberitahukan jadwal pasti posyandu tetapi karena daya ingat yang sudah mulai menurun maka tetap saja lupa dan juga keluarga hendaknya bisa memberikan motivasi yang kuat karena dukungan keluarga ini sangatlah penting karena keluarga merupakan bagian dari keluarga yang paling dekat.

\section{Hubungan Sikap dengan Perilaku Kunjungan Lansia ke Posyandu Lansia}

Sikap berhubungan sebab akibat dengan perilaku kunjungan ke posyandu lansia. Sikap negatif dari seseorang akan mempengaruhi kunjungan ke posyandu lansia. Dalam hal ini dalam menentukan sikap terhadap kunjungan ke posyandu tidak terlepas dari pengetahuan, jadi dari hasil pengetahuan yang baik akan menghasilkan sikap yang positif dalam melakukan kunjungan ke posyandu lansia. Untuk itu diperlukan pengetahuan pengetahuan melalui promosi kesehatan sehingga dengan meningkatnya pengetahuan tersebut nantinya akan menjadi dasar dalam penentuan sikap dan sikap yang baik itulah nantinya akan mendorong minat seseorang untuk berkunjung ke posyandu. Karena apabila seseorang telah berpengetahuan baik maka mereka akan cenderung bersikap positif. Namun sebaliknya apabila seseorang bersikap negatif mereka lebih cenderung menganggap bahwa tidak pentingnya berkunjung ke posyandu lansia tiap bulannya.

\section{Hubungan Akses dengan Perilaku Kunjungan Lansia ke Posyandu Lansia}

Akses berhubungan sebab akibat dengan perilaku kunjungan ke posyandu lansia. Jauhnya lokasi atau jarak ke posyandu dengan rumah akan mempersulit jangkauan untuk ke posyandu lansia. Dalam hal ini diperlukan bagaimana caranya agar jangkauan ke posyandu lebih mudah tanpa harus menyebabkan kelelahan maupun penurunan daya fisik seseorang. Oleh karena itu diperlukan agar keluarga selalu mengantarkan ke fasilitas pelayanan kesehatan yaitu posyandu lansia. Karena dengan adanya keluarga yang mengantar maka jarak tempuh akan mudah dijangkau. Karena jarak tempuh dari rumah ke posyandu merupakan faktor pendukung (enabling) untuk terjadinya perubahan perilaku kesehatan sehingga nantinya menimbulkan minat seseorang untuk mengunjungi posyandu lansia. 


\section{Hubungan Pendidikan dengan Perilaku Kunjungan Lansia ke Posyandu Lansia}

Pendidikan berhubungan sebab akibat dengan perilaku kunjungan ke posyandu lansia. Pendidikan merupakan proses pengubahan sikap dan perilaku seseorang atau kelompok orang dalam usaha mendewasakan seseorang melalui upaya pengajaran dan pelatihan. Tingkat pendidikan secara langsung merupakan salah satu faktor yang ikut mempengaruhi dalam kunjungan ke posyandu lansia. Dalam hal ini pendidikan tidak bisa diintervensi secara langsung oleh sektor kesehatan, oleh sebab itu diperlukan informasi melalui pendidikan kesehatan seperti penyuluhan sehingga dengan diberikannya pengetahuan tentang manfaat posyandu lansia, walaupun dengan pendidikan rendah akan membantu keefektifan peningkatan jumlah lansia ke posyandu lansia tetapi bila tidak diwujudkan secara nyata untuk datang ke posyandu lansia tetap saja tidak memberikan pengaruh bagi perkembangan kunjungan ke posyandu lansia.

\section{KESIMPULAN}

Variabel yang mempunyai hubungan sebab akibat terhadap perilaku kunjungan lansia ke posyandu lansia di wilayah kerja Puskesmas Kampar Kabupaten Kampar adalah pengetahuan, tidak berperannya petugas kesehatan, tidak adanya dukungan keluarga, sikap negatif, akses jauh, dan pendidikan rendah berhubungan dengan perilaku kunjungan lansia ke posyandu lansia di wilayah kerja Puskesmas Kampar Kabupaten Kampar Tahun 2013

\section{SARAN}

Petugas melakukan konseling dan promosi kesehatan melalui media yang menarik seperti ceramah, tanya jawab, leaflet. Promosi kesehatan dilakukan secara terencana, terarah, dan berkesinambungan yang dituang dalam SAP (Satuan Acara Penyuluhan) agar meningkatkan pengetahuan sehingga lansia akan termotivasi untuk berkunjung ke posyandu dan target SPM (Standar Pelayanan Minimal) yang ditetapkan oleh pemerintah sebesar $70 \%$ dapat tercapai.

\section{UCAPAN TERIMA KASIH}

Ucapan terimah kasih kepada Keluarga Tercinta, Ayahanda Pembimbing I yaitu Prof. Dr. Drg. Budi Harto, SKM dan Pembimbing II Emy Leonita, SKM, MPH yang telah banyak memberikan dukungan, arahan, bimbingan, masukan serta koreksi kepada peneliti, Kepala Puskesmas Kampar yang telah memberikan izin penelitian, dan seluruh staff Prodi Magister IKM yang telah membantu secara moril.

\section{DAFTAR PUSTAKA}

Azwar, A (2005). Pengantar Administrasi Kesehatan, Jakarta: Bina Rupa Aksara.

Asfiyati, (2012). Faktor-faktor Yang Berhubungan Dalam Program Pembinaan Kelompok Lansia di Wilayah Kerja Puskesmas Mantrijeron Yogyakarta. Thesis Pasca Sarjana Yogyakarta.

DepKes RI, (2003). Pedoman pengelolaan kegiatan kesehatan di kelompok usia lanjut, Jakarta: DepKes RI.

DepKes RI, (2004). Buku pedoman upaya pembinaan kesehatan jiwa usia lanjut, Jakarta: DepKes RI.

DepKes RI, (2005). Pedoman pembinaan kesehatan usia lanjut bagi petugas kesehatan.

DepKes RI, (2006). Pedoman kemitraan lintas sektor dalam pembinaan lanjut usia edisis ke II.

DinKes Provinsi Riau, (2011). Profil Kesehatan Provinsi Riau: Dinas Kesehatan Provinsi Riau.

DinKes Kabupaten Kampar, (2013). Profil Kesehatan Kabupaten Kampar: Dinas Kesehatan Kabupaten Kampar.

Erfandi, (2008). Pengelolaan Posyandu Lansia.http:/bascommetro.

Blogspot.com/pengelolaan-posyandu lansia, diakses 4 Maret 2013.

Firmani, (2009). Faktor-Faktor yang Berhubungan Dengan Tingkat Kehadiran Lansia di Posyandu Lansia Melati V Kelurahan Karangayu. Thesis Pascasarjana Universitas Semarang.

Hardywinoto, (2005). Panduan Gerontologi. Jakarta: Gramedia.

Henniwati, (2008). Faktor-faktor Yang Mempengaruhi Pemanfaatan Pelayanan Posyandu Lanjut Usia Di Wilayah Kerja Puskesmas Sakti Kabupaten Aceh Timur. Tesis Pascasarjana Universitas Sumatera Utara.

Lapau, B (2012). Metodologi Penelitian Kesehatan Pekanbaru. STIKes Hang Tuah.

Maryam, R dkk (2008). Mengenal usia lanjut dan perawatannya, Jakarta: Salemba Medika.

Undang-Undang Republik Indonesia No. 36 Tahun 2008 tentang kesehatan, Jakarta : Nuansa Aulia. 